\title{
Neural Regulation of N-Cadherin Gene Expression in Developing and Adult Skeletal Muscle
}

\author{
Chang-gyu Hahn ${ }^{\mathrm{a}}$ and Jonathan Covault \\ Department of Physiology and Neurobiology, University of Connecticut, Storrs, Connecticut 06269
}

\begin{abstract}
Using monoclonal antibody and cDNA probes, we have studied $\mathrm{N}$-cadherin gene expression in developing and adult chick skeletal muscle. $\mathrm{N}$-cadherin was expressed by developing myotubes during the period of initial nerve-muscle contact but was downregulated within days of innervation. Treatment of embryos with d-tubocurare partially reversed this downregulation. In the adult, there were muscle fiber type differences in $\mathrm{N}$-cadherin expression. $\mathrm{N}$-cadherin was undetectable on normally innervated twitch fibers, while multiply innervated tonic muscle fibers expressed low but readily detectable levels of $\mathrm{N}$-cadherin. Denervation led to the renewed expression of $\mathrm{N}$-cadherin in twitch fibers as well as a marked increase in expression in tonic fibers. Levels of $\mathrm{N}$-cadherin expressed by tonic fibers could also be modulated by animal housing conditions that favored either increased or decreased levels of daily motor activity. Increased motor activity was correlated with decreased levels of $\mathrm{N}$-cadherin, while decreased motor activity correlated with increased levels of muscle $\mathrm{N}$-cadherin. Results of in vitro studies using the calcium channel agonist ryanodine suggest that changes in intracellular calcium may be the initial signal linking neural stimulation with changes in muscle fiber expression of $\mathrm{N}$-cadherin. Together, our results indicate that neural stimulation of chick skeletal muscle fibers dynamically and reversibly downregulates the expression of $\mathrm{N}$-cadherin mRNA and protein. This pattern of regulation may be functionally important in limiting and/or promoting axon growth in innervated versus denervated muscle and may serve as a molecular model system for studies of the activitydependent regulation of gene expression.
\end{abstract}

Cell adhesion molecules are thought to play important roles in the development and maintenance of the highly ordered cytoarchitecture of the nervous system (Rutishauser and Jessel, 1988; Covault, 1989). It is now becoming clear that most neurons, axon pathways, and potential synaptic targets express mul-

\footnotetext{
Received Jan. 3, 1992; revised June 2, 1992; accepted June 12, 1992.

We thank M. Takeichi for providing the NCD-2 mAb cell line and the Ncadherin pN2 cDNA, R. Schwartz for providing the GAPD pGAD-28 cDNA clone, and $\mathrm{L}$. Landmesser for providing samples of the $\mathrm{CaS} / \mathrm{Cl}$ and $\mathrm{CaF} 1 \mathrm{mAbs}$. We thank Karen Berle for her tireless technical assistance in all aspects of this work and Marjorie Lexton for her expert care of postsurgical animals. This work was supported by NIH Grants NS25264 and RR05933, the March of Dimes Birth Defects Foundation, and the University of Connecticut Research Foundation.

Correspondence should be addressed to Jonathan Covault, Department of Physiology and Neurobiology, Box U-42, University of Connecticut, Storrs, CT 06269 3042 .

aPresent address: Department of Psychiatry, University of Pennsylvania Medical School, Philadelphia, PA 19104.

Copyright (C) 1992 Society for Neuroscience $0270-6474 / 92 / 124677-11 \$ 05.00 / 0$
}

tiple cell adhesion molecules whose net effects result from a largely unknown intracellular summation of their individual influences. Changes in the relative influence of specific adhesion molecules in such a setting has been shown to produce different patterns of neurite growth (Landmesser et al., 1988; Rutishauser et al., 1988), suggesting that this redundancy in cell adhesion molecules is an important contributor to the subtle choices made by growing axons.

In the neuromuscular system, several cell adhesion molecules have been identified that may contribute to the regulation of nerve-muscle interactions, including NCAM, N-cadherin, fibronectin, laminin, s-laminin, and heparan sulfate proteoglycans (Chiu et al., 1986; Sanes et al., 1986; Hatta et al., 1987; Hunter et al., 1989). Of these, NCAM has received the most study. NCAM is expressed by developing muscle fibers during their period of innervation but is then downregulated late in development (Moore and Walsh, 1985; Covault and Sanes, 1986; Tosney et al., 1986). In the adult, interruption of innervation leads to a renewed expression of muscle fiber NCAM (Covault and Sanes, 1985; Rieger et al., 1985; Moore and Walsh, 1986; Cashman et al., 1987). Parallels between the expression of muscle NCAM and the susceptibility of muscle fibers to innervation suggest that NCAM is one of the molecular markers used by muscle fibers to promote neurite growth and innervation. Several in vitro and in vivo studies using blocking antibodies to NCAM (Rutishauser et al., 1983; Bixby et al., 1987; Landmesser et al., 1988; Booth et al., 1990) have provided support for this hypothesis.

In this study, we have examined the expression of a second, well-characterized neural cell adhesion molecule, N-cadherin, in developing and adult muscle. $\mathrm{N}$-cadherin is one member of a family of $\mathrm{Ca}^{2+}$-dependent cell adhesion molecules that are thought to play key roles in histogenesis throughout the vertebrate body (Takeichi, 1990). The ectopic expression of $\mathrm{N}$-cadherin can lead to the disruption of normal developmental morphogenetic events (Detrick et al., 1990; Fujimori et al., 1990). In the nervous system, $\mathrm{N}$-cadherin may be an important stimulus of neurite growth. Purified $\mathrm{N}$-cadherin promotes neurite outgrowth in vitro (Bixby and Zhang, 1990), while anti-N-cadherin antibodies reduce neurite growth on a variety of cellular substrates expressing N-cadherin (Bixby et al., 1988; Matsunaga et al., 1988; Tomaselli et al., 1988; Drazba and Lemmon, 1990; Letourneau et al., 1990) including primary myotubes (Bixby et al., 1987). Previous studies on the expression of $\mathrm{N}$-cadherin in the neuromuscular system have shown that N-cadherin is expressed at high levels by newly formed myotubes and is then downregulated on myofibers to very low levels at some point prior to hatching (Hatta et al., 1987). In light of prior studies 
of muscle fiber expression of NCAM (Covault and Sanes, 1985; Rieger et al., 1985; Moore and Walsh, 1986), this pattern of developmental expression of muscle $\mathrm{N}$-cadherin suggested to us that innervation may be an important component in the regulation of muscle fiber $\mathrm{N}$-cadherin expression. In support of this idea, we show here that the expression of skeletal muscle $\mathrm{N}$ cadherin is inversely correlated with muscle fiber stimulation/ contraction during development, in the adult and in primary myotube cultures.

\section{Materials and Methods}

Animals, surgery, and cell culture. White Leghorn (Gallus gallus) fertile chicken eggs were obtained from the University of Connecticut poultry farm and were incubated in a forced draft rotary incubator at $38^{\circ} \mathrm{C}$. Stages of development were determined as described by Hamburger and Hamilton (1951). For embryos treated with d-tubocurare, eggs were windowed on day 3 of incubation and $100 \mu \mathrm{l}$ of saline or saline containing $20 \mathrm{mg} / \mathrm{ml} d$-tubocurare was applied daily to the chorioallantoic membrane for $2-5 \mathrm{~d}$. The shank muscles of adult (3-6 month old) chickens were denervated by removing a segment of the sciatic nerve at the mid-thigh level under Ketaset (Aveco, Fort Dodge, IA) and Metofane (Pitman-Moore, Inc., Washington Crossing, NJ) anesthesia. The lateral head of the pectoralis major was denervated by cutting the pectoralis nerve via an axillary incision. Adult animals were housed singly in either standard sized $0.43 \mathrm{~m}(\mathrm{~W}) \times 0.5 \mathrm{~m}(\mathrm{D}) \times 0.38 \mathrm{~m}(\mathrm{H})$ cages or in some experiments as a groups of three or four in a $3 \mathrm{~m} \times 1.2 \mathrm{~m}$ room containing a roost $1 \mathrm{~m}$ above the floor level. Embryos were killed by decapitation, and adults, by decapitation under Ketaset anesthesia.

Primary myotube cultures were prepared by mechanical dissociation of thigh muscle from stage 37 (St. 37) embryos. Myoblasts were plated on calf skin collagen-coated dishes at $10^{5}$ cells $/ \mathrm{ml}$ in Dulbecco's minimum essential medium containing $10 \%$ horse serum (GIBCO, Grand Island, NY), $2 \%$ chick embryo extract, $50 \mathrm{U} / \mathrm{ml}$ penicillin, and $50 \mu \mathrm{g} /$ $\mathrm{ml}$ streptomycin. Cultures were treated with $10^{-5} \mathrm{M}$ cytosine arabinoside on days 3 and 4, after which time $10 \mathrm{~nm}$ triiodothyronine was added to the culture media. Myotubes began spontaneously contracting on day $5-6$. Experimental cultures were incubated with tetrodotoxin $(0.5 \mu \mathrm{M})$ and/or ryanodine $(0.1 \mu \mathrm{M})$ for $48 \mathrm{hr}$ beginning on day 7 .

Histology. Tissues were frozen by immersion in dry ice-cooled isopentane. Cryostat sections (6-24 $\mu \mathrm{m}$ thick) were collected on gelatinsubbed slides and stored at $-20^{\circ} \mathrm{C}$ until used. Slides were stained unfixed or after fixation by immersion in ice cold acetone for $1 \mathrm{~min}$. Acctone fixation reduced staining intensity but produced better histologic preservation. Sections were stained for $\mathrm{N}$-cadherin by three sequential 30 min incubations with the rat anti-chicken NCD-2 monoclonal antibody (mAb; Hatta and Takeichi, 1986; $2 \mu \mathrm{g} / \mathrm{ml}$ ), affinity-purified rabbit antiNCD-2 IgG $(1 \mu \mathrm{g} / \mathrm{ml})$, and finally fluorescein-conjugated goat anti-rabbit $\operatorname{IgG}$ ( $1: 150$ dilution; Boehringer Mannheim Biochemicals). For doublelabeling studies, mouse $m A b s$ to the cardiac and pectoral muscle caicium ATPase isoforms (3H2 and 5D2; Kaprielian and Fambrough, 1987) were included in the second incubation followed by addition of rhodamine-conjugated goat anti-mouse IgG in the third incubation. The $\mathrm{mAbs} 3 \mathrm{H} 2$ and $5 \mathrm{D} 2$ are referred to as $\mathrm{mAb} \mathrm{CaS} / \mathrm{Cl}$ and $\mathrm{CaF} 1$, respectively, in keeping with Kaprielian and Fambrough's original nomenclature. In some experiments, sections were stained with the slow myosin mAb S58 (Miller et al., 1985). Teased fibers were stained with rhodamine-conjugated $\alpha$-bungarotoxin $(1 \mu \mathrm{g} / \mathrm{ml}$; Molecular Probes, Eugene, OR), fixed for $1 \mathrm{hr}$ in $4 \%$ formaldehyde in PBS, blocked with $0.1 \mathrm{M}$ glycine (pH 9), and stained with the calcium-ATPase mAbs $3 \mathrm{H} 2$ or $5 \mathrm{D} 2$ in the presence of $0.3 \%$ Triton $\mathrm{X}-100$ followed by fluoresceinconjugated goat anti-mouse IgG. Slides were mounted in 10\% PBS, $90 \%$ glycerol containing $p$-phenylenediamine (Johnson and De C. Noguiera Araujo, 1981) to prevent quenching, and examined using a Zeiss inverted fluorescence microscope. Images of teased fiber bundles were obtained using a Bio-Rad MRC 600 Laser Scanner and are straight projections of eight $2 \mu \mathrm{m}$ serial z-sections.

Immunoblot analysis. Tissues were homogenized on ice in $5 \mathrm{vol}$ of PBS containing $0.5 \%$ NP-40, $2 \mathrm{mM}$ EDTA, and $0.2 \mathrm{TIU} / \mathrm{ml}$ aprotinin. NP-40-soluble protein extracts were obtained by centrifuging the homogenate at $22,000 \times g$ for $20 \mathrm{~min}$. Extracted proteins were separated on $7.5 \%$ polyacrylamide SDS gels and transferred (Towbin ct al., 1979) to Immobilon-P membranes (Millipore, Bedford, MA). For adult mus- cle samples, $\mathrm{N}$-cadherin was immunoprecipitated using NCD-2 agarose (prepared using Amino Link resin, Pierce Chemical, Rockford, IL) prior to electrophoresis. Immunoblots were incubated sequentially for $2 \mathrm{hr}$ each with $\mathrm{NCD}-2 \mathrm{~m} \wedge \mathrm{b}(0.5 \mu \mathrm{g} / \mathrm{ml})$, affinity-purified rabbit anti-NCD$2(1 \mu \mathrm{g} / \mathrm{ml})$ and alkaline phosphatasc-conjugated goat anti-rabbit IgG (1:2500: Boehringer Mannheim Biochemicals). Alkaline phosphatase enzyme activity was localized by a $5 \mathrm{~min}$ incubation in $0.1 \mathrm{M}$ Tris- $\mathrm{HCl}$ (pH 9.5), $10 \mathrm{~mm} \mathrm{MgCl}$, containing $165 \mu \mathrm{g} / \mathrm{ml}$ 5-bromo-4-chloro-3-indolyl phosphate and $330 \mu \mathrm{g} / \mathrm{ml}$ nitroblue tetrazolium. Molecular weight markers (Sigma, St. Louis, MO) used to calibrate the gels were $\alpha_{2}$-macroglobulin $(180 \mathrm{kDa}), \beta$-galactosidase $(116 \mathrm{kDa})$, and pyruvate kinase $(58 \mathrm{kDa})$.

$R N A$ isolation. Total RNA was isolated from embryonic muscle and tissue culture cells using the acid guanidine thiocyanate procedure described by Chomczynski and Sacchi (1987). Briefly, $100 \mathrm{mg}$ of embryonic muscle or primary muscle culture cells from $100 \mathrm{~mm}$ plates were homogenized in $1 \mathrm{ml}$ of $4 \mathrm{M}$ guanidine thiocyanate (Fluka, Ronkonkoma, NY), $25 \mathrm{~mm}$ sodium citratc ( $\mathrm{pH} 7.0$ ), $0.5 \%$ sodium lauryl sarcosine, and $0.1 \mathrm{M} \beta$-mercaptoethanol. Then was added $0.1 \mathrm{ml}$ of $2 \mathrm{M}$ $\mathrm{Na}$ acetate ( $\mathrm{pH} 4.0$ ), followed by $1 \mathrm{ml}$ of water saturated phenol and $0.2 \mathrm{ml}$ of chloroform. The suspension was chilled on ice for $20 \mathrm{~min}$ and centrifuged at $10,000 \times g$ for $20 \mathrm{~min}$. RNA was recovered from the supernatant by addition of 1 vol of isopropanol. Precipitated RNA was dissolved in RNase-free TE buffer (10 mM Tris-HCl, pH 7.4, $1 \mathrm{~mm}$ EDTA). For adult muscle, total RNA was isolated by centrifugation through cesium chloride (Chirgwin et al., 1979). Briefly, $1 \mathrm{gm}$ of minced tissue was homogenized in $25 \mathrm{ml}$ of GTB solution (4 M guanidium thiocyanate, $0.1 \mathrm{~m}$ Tris, $\mathrm{pH} 7.4$, and $0.1 \mathrm{~m} \beta$-mercaptoethanol) using a polytron homogenizer. Sodium lauryl sarcosine was added to $0.5 \% \mathrm{w} /$ $\mathbf{v}$, and the sample was centrifuged at $10,000 \mathrm{rpm}$ in Beckman JA-20 rotor for $10 \mathrm{~min}$. The supernatant was precipitated by addition of 0.025 $\mathrm{vol}$ of $1 \mathrm{M}$ acetic acid and $0.75 \mathrm{vol}$ of ethanol followed by incubation at $-20^{\circ} \mathrm{C}$ for $2 \mathrm{hr}$. The precipitate was collected by centrifugation at $10,000 \times g$ for $10 \mathrm{~min}$ and was dissolved in $0.5 \mathrm{vol}$ (relative to the original volume) of GTB solution, and $0.43 \mathrm{gm}$ of $\mathrm{CsCl}$ was added per milliliter of sample. Samples were loaded on $3 \mathrm{ml}$ pads of $5.7 \mathrm{M} \mathrm{CsCl}$, $0.1 \mathrm{M}$ EDTA, $\mathrm{pH} 8.0$, and centrifuged at $30,000 \mathrm{rpm}$ in a SW 30.1 rotor for $20 \mathrm{hr}$ at $20^{\circ} \mathrm{C}$. RNA pellets were dissolved in RNase-free $0.1 \% \mathrm{SDS}$, 1 mм EDTA, pH 8.0.

$R$ Nase protection assay. Levels of specific mRNAs were determined using the RNase protection assay described by Little and Jackson (1987). Chicken N-cadherin $\lambda$ N2 cDNA (Hatta et al., 1988) and a PstI fragment of the chicken glyceraldehyde-phosphate dehydrogenase (GAPD) pGAD28 cDNA (Dugaiczyk et al., 1983) were subcloned into the Bluescript $\mathrm{KS}+$ vector (Stratagene, La Jolla, CA) and linearized with SspI or HindIII restriction enzymes, respectivcly, to provide templates for the synthesis of ${ }^{32} \mathrm{P}$-labeled antisense RNAs in vitro. The $\mathrm{N}$-cadherin probe corresponds to a 214 nucleotide $(\mathrm{nt})$ region at the extreme $3^{\prime}$-untranslated end of the mature mRNA. A chicken NCAM cDNA, pNCAM175, was prepared by subcloning a reverse-transcribed, PCR-amplified $175 \mathrm{nt}$ segment of chicken brain NCAM mRNA corresponding to amino acids 219-276 from exons 7-8 (Hemperly et al., 1986; Owens et al., 1987). The NCAM template was linearized in the upstream polylinker region using EcoRI. Antisense riboprobes were synthesized in vitro using T7 RNA polymerase (Promega, Madison, WI) in the presence of $400 \mathrm{Ci}$ mmol ${ }^{32} \mathrm{P}$-UTP (Amersham, Arlington Heights, IL) for N-cadherin and NCAM and either $400 \mathrm{Ci} / \mathrm{mmol}$ or $20 \mathrm{Ci} / \mathrm{mmol}{ }^{32} \mathrm{P}$-UTP for GAPD. The full-length and gene-specific complimentary lengths, respectively, of the probes were as follows: N-cadherin, 290, 214; GAPD, 230, 168; NCAM, 243, 175. Each probe $\left(2 \times 10^{5} \mathrm{cpm}\right)$ was hybridizcd with 20 $\mu \mathrm{g}$ of total RNA in $30 \mu \mathrm{l}$ of $80 \%$ formamide, $40 \mathrm{~mm}$ 1,4-piperazinediethanesulfonic acid (pH 6.8), $400 \mathrm{~mm} \mathrm{NaCl}$, and $1 \mathrm{~mm}$ EDTA for 20 $\mathrm{hr}$ at $42^{\circ} \mathrm{C}$. Samples were diluted 10 -fold with RNase digestion buffer, $400 \mathrm{~mm} \mathrm{NaCl}, 20 \mathrm{~mm}$ Tris- $\mathrm{HCl}$ (pH 7.5), $3 \mathrm{~mm}$ EDTA, $40 \mu / \mathrm{ml}$ RNase $\mathrm{A}$, and $3 \mu \mathrm{g} / \mathrm{ml}$ RNase $\mathrm{T} 1$ and incubated at $37^{\circ} \mathrm{C}$ for $1 \mathrm{hr}$. Samples were then treated with proteinase $K$, phenol chloroform extracted, ethanol precipitated, and redissolved in $15 \mu \mathrm{l}$ of gel loading buffer $(95 \%$ formamide, $10 \mathrm{~mm}$ EDTA, $0.05 \%$ xylene cyanol, and $0.05 \%$ bromophenol blue). One-half of each sample (representing approximately $10 \mu \mathrm{g}$ of total RNA) was then analyzed on $6 \%$ polyacrylamide $7 \mathrm{M}$ urea sequencing gels. In control experiments, each probe was separately hybridized with samples of positive (brain) and negative (liver) control RNA in order to identify the protected fragments corresponding to each probe. The N-cadherin probe produced a doublet of 211-214 nt; the relative intensity of the two bands varied between individual experiments. The 
presence of the doublet may reflect variable cleavage at the SspI cut 3'end of the gene-specific portion of the probe ending in AAU. The NCAM riboprobe produced, in addition to the expected $175 \mathrm{nt}$ fragment, an $\approx 200 \mathrm{nt}$ fragment whose intensity paralleled that of the more intense $175 \mathrm{nt}$ fragment. The origin of this minor fragment is unclear. Levels of N-cadherin and NCAM RNAs were quantitated by densitometric scanning of suitably exposed autoradiograms. For both N-cadherin and NCAM, the intensities of the two bands corresponding to each gene probe were combined. Film intensities were converted to moles by comparing the signals from protected fragments with that of a known amount of undigested ${ }^{32} \mathrm{P}$-labeled riboprobe after correction for the molar fraction of uridine in each probe. Data for each sample were normalized to the intensity of the GAPD signal for that sample. The average intensity of GAPD signals for each experiment was considered to represent $10 \mu \mathrm{g}$ of total RNA and was used together with the normalized data for each sample to yield an estimation of the molar amount of specific RNA per $10 \mu \mathrm{g}$ of total RNA. For all experiments combined, the level of GAPD RNA was $69 \pm 7 \mathrm{SE}$ amol$/ 10 \mu \mathrm{g}$ total RNA $(n=$ 24).

\section{Results}

\section{$N$-cadherin expression in developing chick skeletal muscle}

In agreement with previous studies (Hatta et al., 1987), Ncadherin was expressed at high levels by developing chick muscle fibers during the period of synaptogenesis (St. 30-36; Fig. $1 A$ ) and on the surface of both myoblasts and myotubes in primary muscle cultures (not shown). The distribution of $\mathrm{N}$ cadherin both in vivo and in vitro was relatively uniform along the developing myotube surface. Levels of myofiber $\mathrm{N}$-cadherin immunoreactivity in cryostat sections remained high until St. 35-36, after which there was a marked decline for most fibers to quite low levels by St. $39-40$ (Fig. $1 B, C$ ). Weak N-cadherin immunoreactivity persisted on large-diameter fibers (Fig. $1 C$ ), which corresponded to slow myosin mAb S58-positive fibers. To identify better the time course of the developmental downregulation of $\mathrm{N}$-cadherin gene expression in order to relate it to the period of muscle innervation/activation, and to ask whether decreased levels of $\mathrm{N}$-cadherin protein were associated with changes in the level of N-cadherin mRNA, we used an RNase protection assay to measure levels of N-cadherin RNA in developing chick leg muscle (Fig. $2 A$ ). In parallel with our histologic results of $\mathrm{N}$-cadherin expression, $\mathrm{N}$-cadherin mRNA levels declined most rapidly during the $4 \mathrm{~d}$ period between St. 36 and St. 40 of chick development. During this period, levels of Ncadherin mRNA declined approximately 10-fold from 6 to 0.5 amol per $10 \mu \mathrm{g}$ total RNA. The sharp decline in $\mathrm{N}$-cadherin mRNA occurs shortly after the development of large numbers of nascent synapses between St. 33 and St. 36 in chick leg muscle (Dahm and Landmesser, 1991) and overlaps the development of robust spontaneous neuromuscular activity (Hamburger et al., 1965; Provine, 1972; Oppenheim, 1975). Thus, the time course of decline in N-cadherin mRNA is consistent with the hypothesis that nerve-induced myotube depolarization or contraction leads to a downregulation of $\mathrm{N}$-cadherin gene expression. As one test of this hypothesis, we treated some embryos with $d$-tubocurare to block neuromuscular transmission. In two embryos, we carried out short-term ( 2 d) $d$-tubocurare treatments late in development (St. 39-41 and St. 40-42) while two other embryos were treated for longer periods (4 and $5 \mathrm{~d}$, St. $39-43$ and St. 27-36). Following a 2 d treatment, levels of leg muscle $\mathrm{N}$-cadherin mRNA were increased fivefold in one experiment (6.7 vs 1.3 amol per $10 \mu \mathrm{g}$ total RNA for paired St. $41 d$-tubocurare vs saline-treated embryos) and threefold in a second ( 2.3 vs $0.7 \mathrm{amol} / 10 \mu \mathrm{g}$ RNA for paired St. $42 d$-tubo-
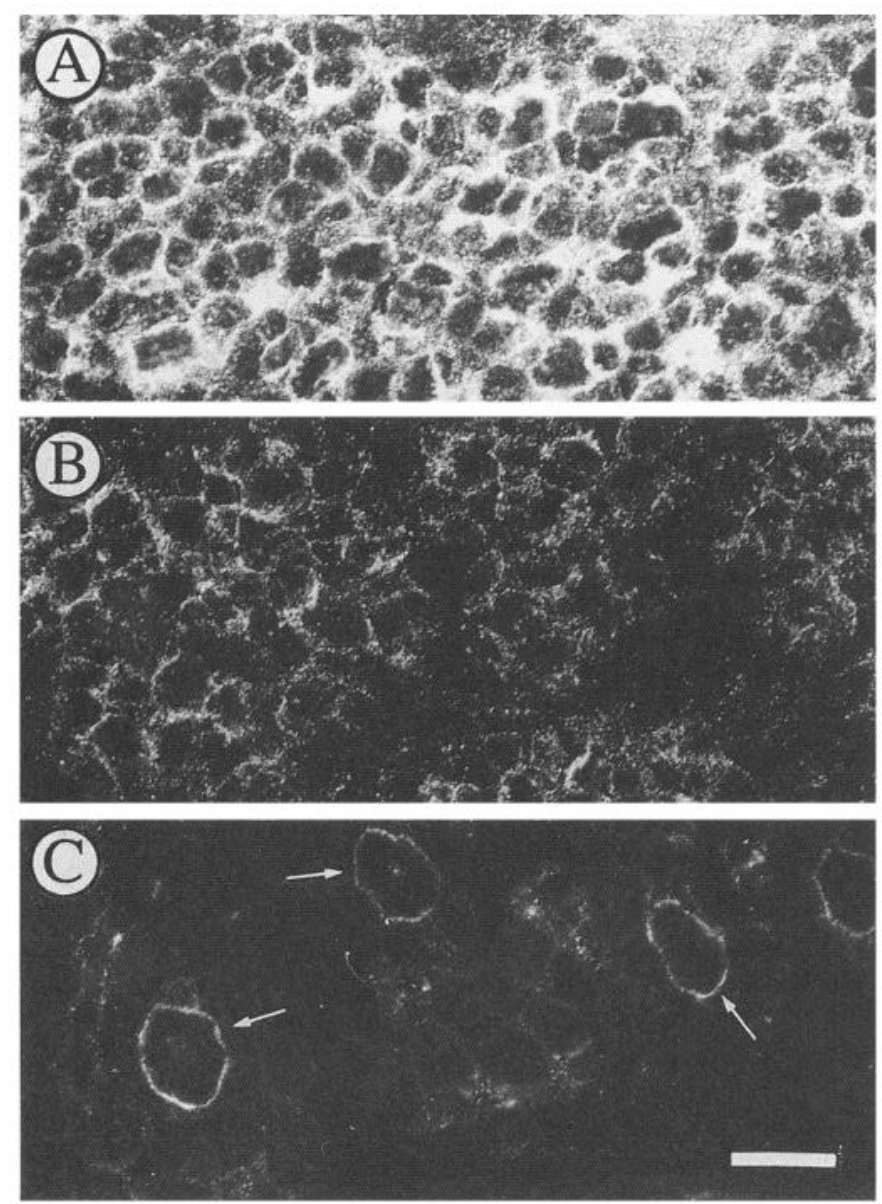

Figure 1. Cryostat sections of St. $33(A)$, St. $37(B)$, and St. $40(C)$ chick thigh muscle stained with NCD-2 mAb and fluorescein-conjugated secondary antibody. St. 33 myotubes express $\mathrm{N}$-cadherin immunoreactivity, which is markedly reduced by St. 37 and nearly undetectable on most fibers by St. 40. A subset of fibers continue to show weak NCD2 immunoreactivity in late-stage embryos (arrows in $C$ ); this set of fibers corresponds to $\mathrm{mAb} \mathrm{S58}$ slow myosin-positive fibers.

curare vs saline-treated embryos). In the embryos treated for 4 and $5 \mathrm{~d}$, the levels of muscle $\mathrm{N}$-cadherin mRNA were only slightly or not increased (1.7- and 1.0-fold, respectively). The apparent failure of long-term paralysis to block the decline in $\mathrm{N}$-cadherin mRNA may reflect both toxic and secondary developmental effects that long-term $d$-tubocurare treatments have on embryos including extensive venous pooling, notable histologic and developmental changes in muscle fibers (Fredette and Landmesser, 1991), and an $\approx 20 \%$ mortality in most studies. Thus, short-term paralysis of developing muscle with $d$-tubocurare blocks and partially reverses the developmental decline of N-cadherin mRNA expression. Complications of longer-term $d$-tubocurare treatments prevented us from more clearly addressing the extent to which the overall 10-15-fold decrease in $\mathrm{N}$-cadherin expression during development is triggered by innervation. As described below, the influence of muscle fiber innervation on $\mathrm{N}$-cadherin expression can be more clearly examined in adult animals.

The time course of decreased $\mathrm{N}$-cadherin protein expression in developing chick muscle was noted to be markedly different from that previously reported for NCAM (Covault and Sanes, 1986; Tosney et al., 1986). In the adult, NCAM is known to be 

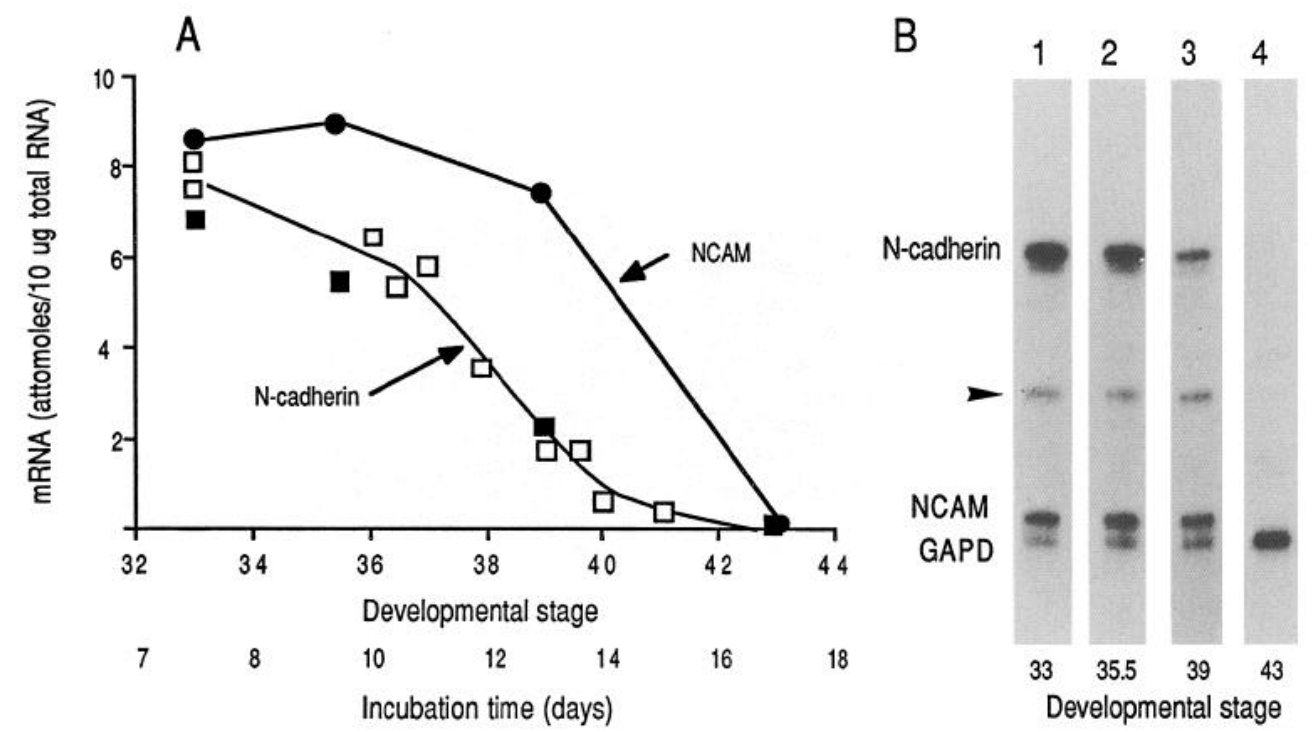

Figure 2. RNase protection analysis of N-cadherin and NCAM mRNA levels in developing chick muscle. A, Levels of N-cadherin (squares) or NCAM (circles) mRNA were measured using an RNase protection assay and total RNA isolated from staged embryo thigh muscle. The data shown are a compilation from several experiments; samples within each experiment were normalized to the amount of GAPD mRNA present in each sample, which did not vary significantly during the developmental period examined. The solid symbols indicate the results obtained from the autoradiogram shown in $B$. B. Autoradiogram of an RNase protection assay from one experiment. Positions of the $214 \mathrm{nt} N$-cadherin, $175 \mathrm{nt}$ NCAM, and $168 \mathrm{nt}$ GAPD protected riboprobe fragments are indicated. The N-cadherin probe produces a doublet of $211 / 214 \mathrm{nt}$, while for NCAM, in addition to the expected $175 \mathrm{nt}$ fragment, the riboprobe also produces an $\approx 200 \mathrm{nt}$ fragment indicated by the arrowhead. For both NCAM and $\mathrm{N}$-cadherin, the intensities of the two relevant bands were combined. The GAPD probe was synthesized using ${ }^{32} \mathrm{P}-\mathrm{UTP}$ with $1 / 20$ the specific activity as that used to synthesize the N-cadherin and NCAM probes, as the level of GAPD mRNA $(69 \pm 7 \mathrm{SE}$ amol/10 $\mu \mathrm{g}$ total RNA; $n=24)$ was 10-100 times that of N-cadherin or NCAM mRNAs. After adjustment for the number of U's in each antisense sequence, the specific activity for the protected fragments was $52 \mathrm{dpm} / \mathrm{amol}$ of N-cadherin, $40 \mathrm{dpm} / \mathrm{amol}$ of NCAM, and $1.5 \mathrm{dpm} / \mathrm{amol}$ of GAPD.

downregulated by muscle fiber innervation (Covault and Sanes, 1985; Rieger et al., 1985; Moore and Walsh, 1986). In agreement with earlier results of NCAM expression in developing chick muscle, we find that levels of muscle fiber NCAM immunoreactivity remain high until St. 40 and then begin to decline markedly around St. 43-45 (not shown). In order to test whether this delay in the downregulation of NCAM as compared with $\mathrm{N}$-cadherin simply reflects a slower rate of NCAM protein turnover, we measured the level of leg muscle NCAM mRNA as well as $\mathrm{N}$-cadherin mRNA in one experiment. The results of this experiment are shown in Figure $2 B$ and are plotted together with our data for $\mathrm{N}$-cadherin mRNA from several experiments in Figure $2 A$. In parallel with the different time course of N-cadherin and NCAM protein changes, the downregulation of NCAM mRNA was delayed by 3-4 d as compared with N-cadherin mRNA. A similar 3-4 d delay in the decline of NCAM mRNA as compared with $\mathrm{N}$-cadherin mRNA was also observed using RNA from developing chick breast muscle (J. Covault and J. Capasso, unpublished observations). While the functional significance of the delayed downregulation of NCAM as compared to $\mathrm{N}$-cadherin is not clear, it suggests that the regulation of $\mathrm{N}$-cadherin gene expression is more tightly linked to muscle fiber innervation than is NCAM expression.

\section{$\mathrm{N}$-cadherin expression in innervated adult chick muscle}

The expression of $\mathrm{N}$-cadherin was undetectable by immunofluorescence staining of young adult innervated chick pectoralis muscle. In contrast, some muscle fibers were stained by NCD$2 \mathrm{mAb}$ in red, oxidative fiber-rich leg muscles (Fig. $3 A$ ). These fibers presumably correspond to those fibers that were weakly stained in late embryonic leg muscle (Fig. 1C). N-cadherin- positive adult muscle fibers corresponded to that subset of fibers stained by the $\mathrm{mAb} \mathrm{CaS} / \mathrm{Cl}$ (Fig. $3 A, B$ ), which recognizes a calcium-ATPase isoform expressed by cardiac muscle (Kaprielian and Fambrough, 1987). A second $\mathrm{mAb}, \mathrm{CaF} 1$, which recognizes a calcium-ATPase isoform isolated from pectoral muscle, reacted with all $\mathrm{N}$-cadherin-negative fibers in both breast and leg muscles. By doubly staining teased gastrocnemius muscle fibers with either the $\mathrm{CaS} / \mathrm{Cl}$ or $\mathrm{CaF} 1 \mathrm{mAb}$ together with rhodamine-conjugated $\alpha$-bungarotoxin to mark synaptic sites, we found that $\mathrm{mAb} \mathrm{CaS} / \mathrm{Cl}$-positive fibers corresponded to multiply innervated fibers (Fig. $4 A, B$ ), while $\mathrm{mAb} \mathrm{CaF1-posi-}$ tive fibers were focally innervated (Fig. $4 C, D$ ). Thus, our results indicate that multiply innervated slow-tonic fibers continue to express $\mathrm{N}$-cadherin in adult chick muscle. In contrast, singly innervated adult fast and slow-twitch fibers express undetectable levels of $\mathrm{N}$-cadherin.

\section{Effects of neural stimulation on $\mathrm{N}$-cadherin expression in adult chicken muscle}

Denervation of the gastrocnemius in adult chickens resulted in a marked increase in the level of $\mathrm{N}$-cadherin expression in both tonic and twitch muscle fibers (Fig. 3C,D). An increase in staining was apparent earliest for tonic fibers (within 3-4 d) but reached a comparable level for both types of fibers by 7-10 d. Denervation of the fast-twitch pectoralis muscle induced similar increases in $\mathrm{N}$-cadherin staining. $\mathrm{N}$-cadherin antibodies stained the outer surface of denervated fibers; no staining was detected on intracellular membranes as has been described for NCAM in denervated muscle (Covault and Sanes, 1986).

In addition to muscle fiber staining, we noted that anti-Ncadherin antibodies stained structures within intramuscular nerve 

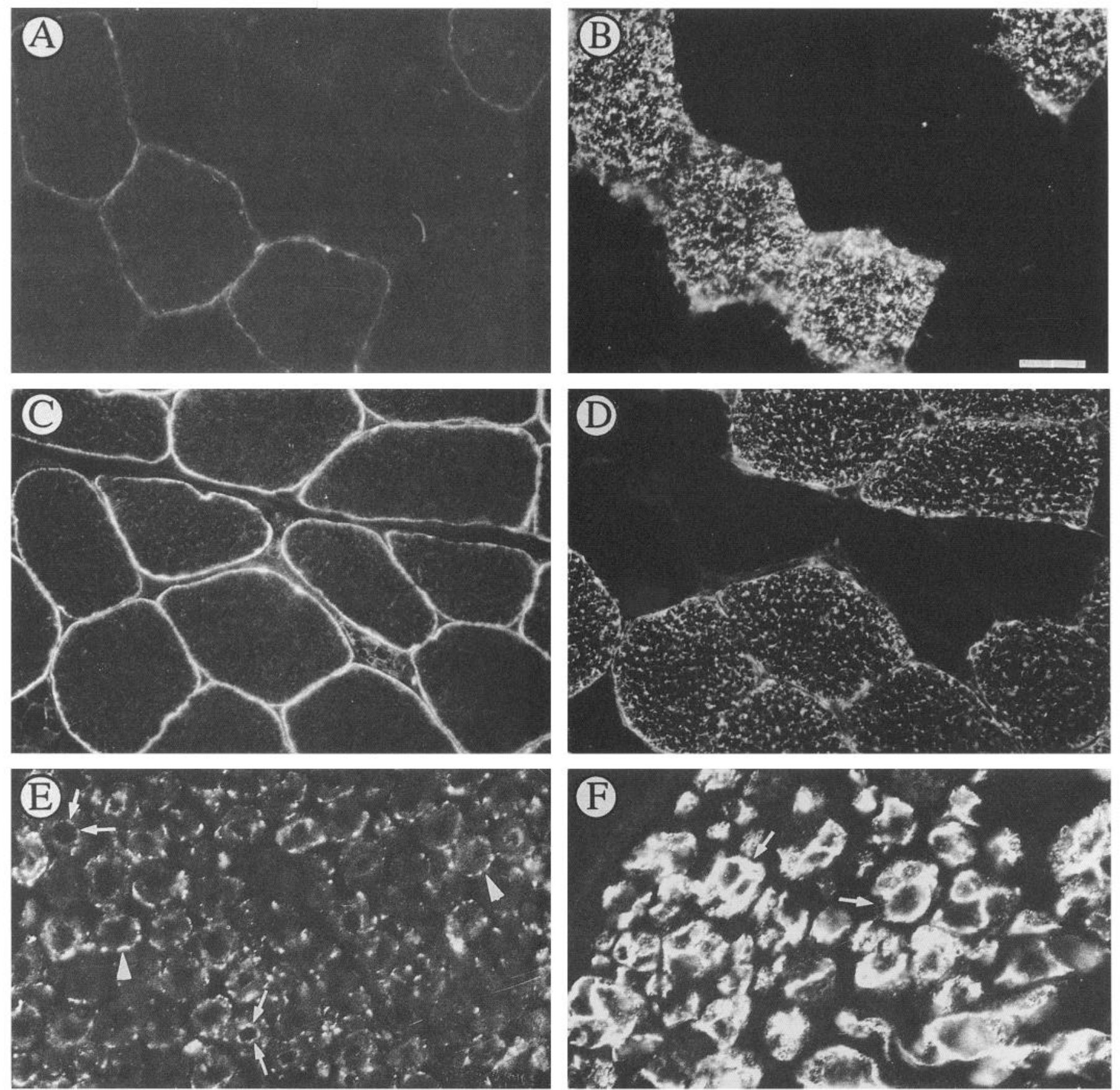

Figure 3. Expression of $\mathrm{N}$-cadherin in innervated and denervated adult muscle. $A-D$, Cryostat cross sections of innervated $(A, B)$ or $6 \mathrm{~d}$ denervated $(C, D)$ adult gastrocnemius muscle doubly stained with NCD-2 mAb $(A, C)$ and the $\mathrm{CaS} / \mathrm{Cl} \mathrm{Ca}-\mathrm{ATPase} \mathrm{mAb}(B, D)$. N-cadherin was detected on the surface of innervated $\mathrm{CaS} / \mathrm{C} 1$-positive fibers. Denervation induced the accumulation of $\mathrm{N}$-cadherin on the surface of both $\mathrm{CaS} / \mathrm{C} 1$-positive and -negative fibers. $E$ and $F$, Cryostat cross sections of a gastrocnemius intramuscular nerve from an untreated animal $(C)$ and from an animal whose sciatic nerve had been cut $6 \mathrm{~d}$ earlier $(C)$, stained with NCD-2 mAb. N-cadherin staining is present in association with the outermost $(E$, arrowheads) and innermost $(E$, arrows) layer of myelin in a punctate distribution in normal peripheral nerve. N-cadherin staining associated with Schwann cell/basal lamina tubes $(F$, arrows) is greatly increased following nerve lesion. Scale bar (in $B$ ): $30 \mu \mathrm{m}$ for $A-D ; 20 \mu \mathrm{m}$ for $E$ and $F$.

trunks. In normal intact nerve, $\mathrm{N}$-cadherin staining was punctate and outlined the outer and inner extent of the Schwann cell/myelin unit (Fig. $3 E$ ). In response to proximal nerve damage, there was a large increase in the amount of intramuscular nerve staining associated with Schwann cell/basal lamina tubes (Fig. $3 F$ ). In light of previous studies showing that Schwann cells grown in vitro express $\mathrm{N}$-cadherin (Hatta et al., 1987; Bixby et al., 1988; Letourneau et al., 1990), these results indicate that changes in the expression of $\mathrm{N}$-cadherin by myelinating Schwann cells is part of the complex response of Schwann cells to axon contact and its withdrawal.

In order to confirm that the increased $\mathrm{N}$-cadherin immunofluorescent staining of denervated muscle fibers reflected an increased expression of $\mathrm{N}$-cadherin protein and not simply an unmasking of $\mathrm{N}$-cadherin epitopes, we compared the level of $\mathrm{N}$-cadherin protein present in detergent extracts of innervated 
Figure 4. Correlations between CaATPase isoforms and focal versus multiply innervated muscle fibers. Teased bundles of 10-20 muscle fibers from a 10-d-old chick medial gastrocnemius were doubly stained with rhodamineconjugated $\alpha$-bungarotoxin $(B, D)$ to label synaptic sites and either the $\mathrm{CaS} /$ $\mathrm{Cl}(A)$ or $\mathrm{CaF} 1(C) \mathrm{Ca}-\mathrm{ATPase} \mathrm{mAbs}$ followed by fluorescein-conjugated secondary antibody. The bundle of muscle fibers shown in $A$ and $B$ contained two fibers stained by the $\mathrm{CaS} / \mathrm{Cl} \mathrm{mAb}$. These two fibers were multiply innervated with synaptic sites (arrows) located at regular intervals of $\approx 200 \mu \mathrm{m}$. The remainder of the fibers in this bundle had a large focal endplates (arrowheads). In contrast, the bundle of fibers shown in $C$ and $D$ contained two fibers stained by the CaF1 mAb. These fibers each have a focal synaptic site (arrowheads); the remainder of the fibers in this particular bundle have multiple, regularly spaced synaptic sites (arrows). Scale bar, $50 \mu \mathrm{m}$.
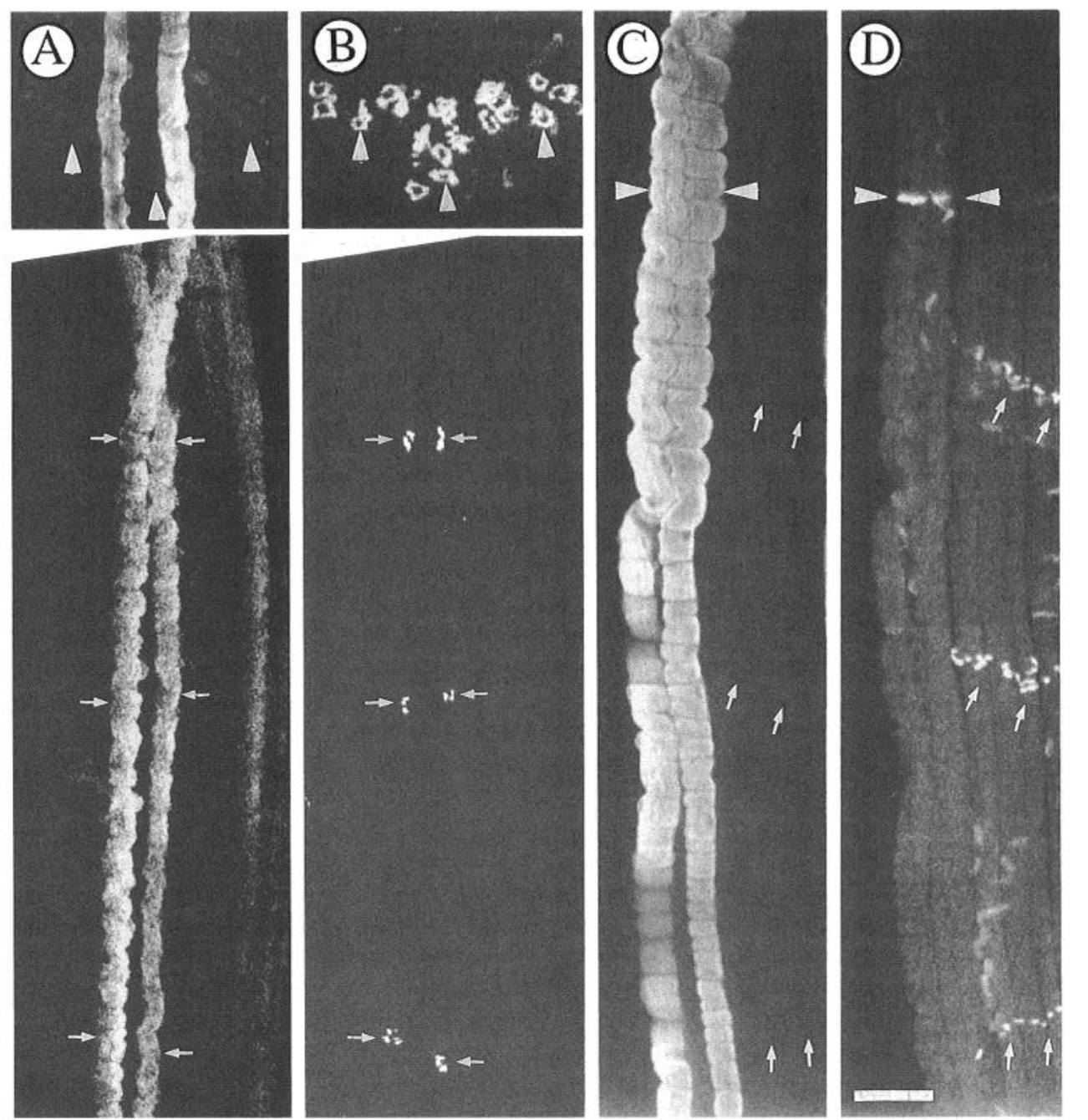

and denervated muscle. An NCD-2-reactive protein with a very similar molecular weight as brain $\mathrm{N}$-cadherin was detected in detergent extracts of St. 33 embryonic and 6 d denervated adult, but not of innervated adult muscle (Fig. 5A), confirming our histological results that denervation of adult chick muscle induces the accumulation of muscle fiber $\mathrm{N}$-cadherin.

In order to test whether the differences in $\mathrm{N}$-cadherin protein levels that we observed in twitch versus tonic, and innervated versus denervated adult muscle, were paralleled by more proximal changes in gene expression, we compared $\mathrm{N}$-cadherin mRNA levels in the lateral (twitch) and medial (twitch and tonic) portions of innervated and denervated adult gastrocnemius muscles. When RNA extracted from the innervated gastrocnemius muscle was analyzed by RNase protection, we found a threefold higher level of $\mathrm{N}$-cadherin $\mathrm{mRNA} / \mu \mathrm{g}$ total RNA in the medial head, which contains approximately $50 \%$ tonic fibers, as compared with the lateral head, which contains exclusively twitch fibers (Fig. $5 B$, lanes 1,2). This difference between the lateral and medial gastrocnemius would correspond to an approximately sixfold difference if the medial sample were entirely slow-tonic fibers. Following $2 \mathrm{~d}$ of denervation, levels of $\mathrm{N}$ cadherin mRNA were increased sixfold for the lateral (twitch) head and eightfold for the medial (twitch and tonic) head (Fig. $5 B$, lanes 3,4$)$. In contrast, the levels of GAPD mRNA were not different in twitch versus tonic and innervated versus de- nervated muscle RNA. Following $7 \mathrm{~d}$ of denervation, the level of N-cadherin mRNA was similar in the two muscles and corresponded to an 11-fold increase for the medial head and a greater than 20 -fold increase for the lateral head (data not shown). The levels of N-cadherin mRNA detected after $7 \mathrm{~d}$ of denervation ( 5 amol per $10 \mu \mathrm{g}$ total RNA) were comparable to that detected in $\approx$ St. 36 embryonic leg muscle. Thus, the differences that we detected in levels of $\mathrm{N}$-cadherin by immunofluorescence in twitch versus tonic and innervated versus denervated adult muscle fibers are paralleled by, and presumably result from, differences in the level of muscle $\mathrm{N}$-cadherin mRNA.

Higher levels of $\mathrm{N}$-cadherin protein and mRNA in innervated tonic as compared to twitch muscle fibers could reflect either qualitative or quantitative differences in $\mathrm{N}$-cadherin gene regulation. Since denervation induces a similar increase in N-cadherin gene expression in both fiber types, we suggest that the higher expression of $\mathrm{N}$-cadherin in innervated tonic as compared to twitch fibers might reflect quantitative rather than qualitative differences in the regulation of $\mathrm{N}$-cadherin gene expression in these two fiber types by nerve stimulation. As an initial step toward testing this idea, we housed groups of three or four chickens together for 3 weeks in a large open area $\left(3.6 \mathrm{~m}^{2}\right)$ of the animal room, which contained a roosting box $1 \mathrm{~m}$ above the floor to which they jumped/flew several times daily. This group of chickens had a much higher level of behavioral motor 

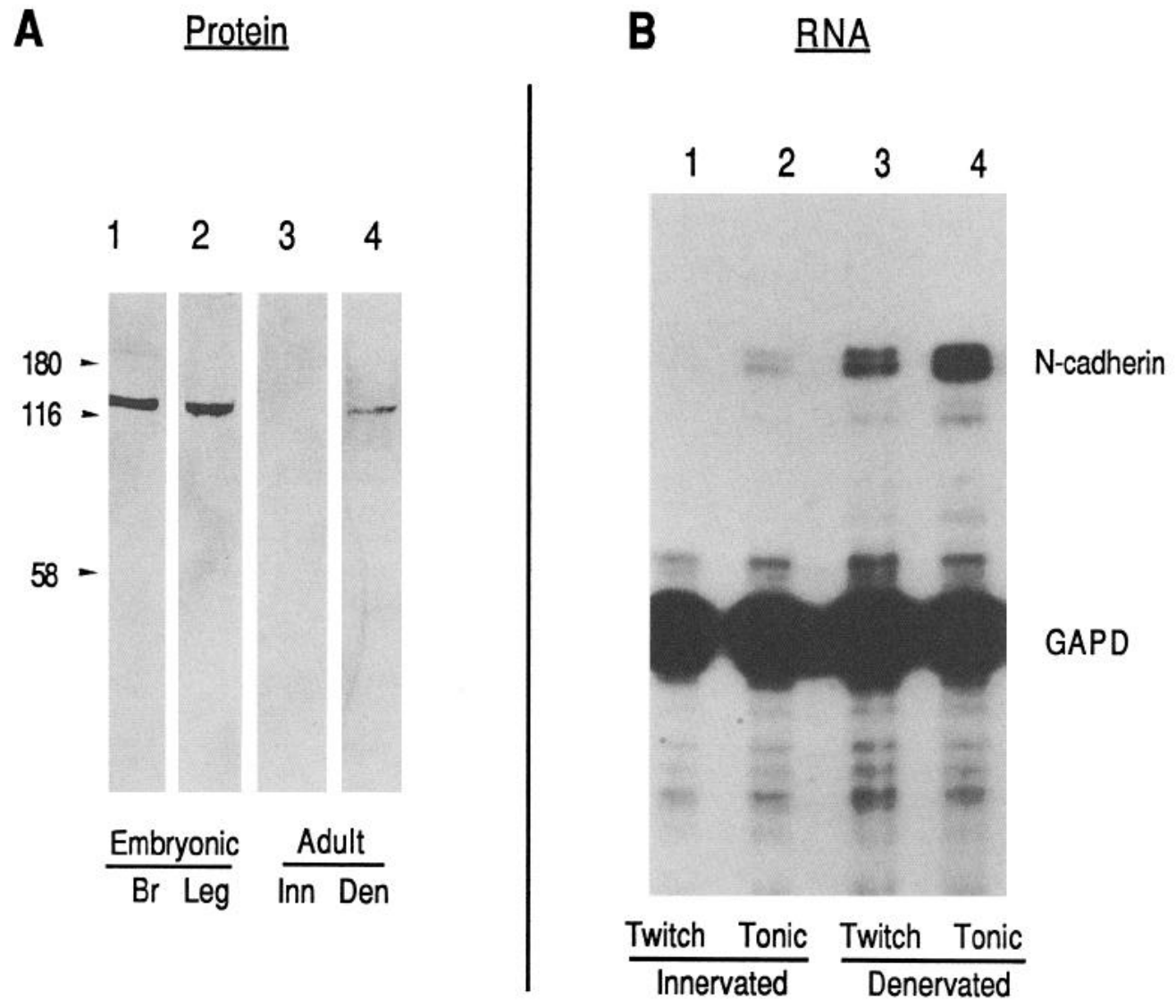

Figure 5. A, Immunoblot analysis of N-cadherin expression in chick muscle. NP-40 detergent extracts of post-hatch day 1 chick brain (lane I), St. 33 leg muscle (lane 2), and adult innervated (lane 3) or denervated (lane 4) proximal portion of the lateral head (fast twitch) of the gastrocnemius probed with NCD-2 mAb and alkaline phosphatase-conjugated second antibody. Denervated, but not innervated, adult muscle contains an NCD2 -reactive protein of the same apparent molecular weight as that detected in chick brain or embryonic muscle. NP-40-soluble protein (10 and 20 $\mu \mathrm{g}$, respectively) was loaded in lanes 1 and 2 . For lanes 3 and 4, N-cadherin was concentrated by immunoprecipitation from $500 \mu \mathrm{g}$ of NP-40soluble protein prior to immunoblot analysis. $B$, RNase protection analysis of adult chicken muscle RNA. Ten micrograms of total RNA extracted from the proximal lateral (Twitch, lanes 1 and 3) or medial (Tonic, lanes 2 and 4 ) heads of innervated (lanes 1 and 2 ) or $2 \mathrm{~d}$ denervated (lanes 3 and 4 ) gastrocnemius muscle were hybridized with ${ }^{32} \mathrm{P}$-labeled $\mathrm{N}$-cadherin and GAPD riboprobes. Riboprobe fragments protected from digestion by their respective cellular RNAs were separated on a sequencing gel and visualized by autoradiography. The medial head of the gastrocnemius contains $\approx 50 \%$ tonic fibers and had a threefold higher level of $\mathrm{N}$-cadherin mRNA than the lateral, exclusively twitch fiber, head. Denervation induces the accumulation of N-cadherin mRNA in both muscle fiber types. In contrast, the level of GAPD mRNA was not effected by fiber type or by denervation. Unlike the experiment shown in Figure $2 B$, both the N-cadherin and GAPD riboprobes used in this experiment were prepared using $400 \mathrm{Ci} / \mathrm{mmol}{ }^{32} \mathrm{P}$-UTP, producing a much broader and darker band for GAPD as compared with the assay shown in Figure $2 B$. A 10 -fold shorter exposure was used to quantitate the GAPD signal.

activity as compared with our standard singly caged chickens $\left(0.2 \mathrm{~m}^{2}\right.$ floor area). Tonic gastrocnemius muscle fibers from the "active" group of chickens (Fig. 6C) contained much lower levels of $\mathrm{N}$-cadherin immunoreactivity as compared with the normally caged animals (Fig. 6A). This downregulation in Ncadherin levels could be reversed by returning these "free-ranging" birds to their standard-sized cages for an additional 3 weeks (Fig. 6D). These results, which were replicated with four animals for each condition, indicate that levels of $\mathrm{N}$-cadherin gene expression in innervated tonic fibers may be regulated by changes in the level of neural activation within normal physiological ranges.

\section{Modulation of $N$-cadherin gene expression in cultured myotubes by TTX and ryanodine}

The regulation of $\mathrm{N}$-cadherin expression by innervation parallels that of the $\mathrm{ACh}$ receptor. Neural stimulation of muscle fibers is thought to downregulate extrasynaptic ACh receptor expression by increasing intracellular calcium levels in response to membrane depolarization (Pezzementi and Schmidt, 1981; Rubin, 1985; Klarsfeld et al., 1989). In order to test whether these early events in excitation-contraction coupling might also be involved in the neural regulation of muscle fiber $\mathrm{N}$-cadherin, we examined the effects of TTX and ryanodine on the level of $\mathrm{N}$-cadherin mRNA in primary chick myotube cultures (Fig. 7). Blockade of the normal spontaneous electrical activity present in primary myotube cultures by the sodium channel blocker TTX for 48 hr produced a $65 \%$ increase in $\mathrm{N}$-cadherin mRNA levels. In contrast, $48 \mathrm{hr}$ treatment with the sarcoplasmic calcium channel agonist ryanodine produced a $50 \%$ reduction in the level of N-cadherin mRNA. These results are consistent with the idea that increased myoplasmic calcium levels accompanying excitation-contraction coupling is the initial intracellular second messenger linking neural activity and the downregulation of muscle fiber $\mathrm{N}$-cadherin expression. 

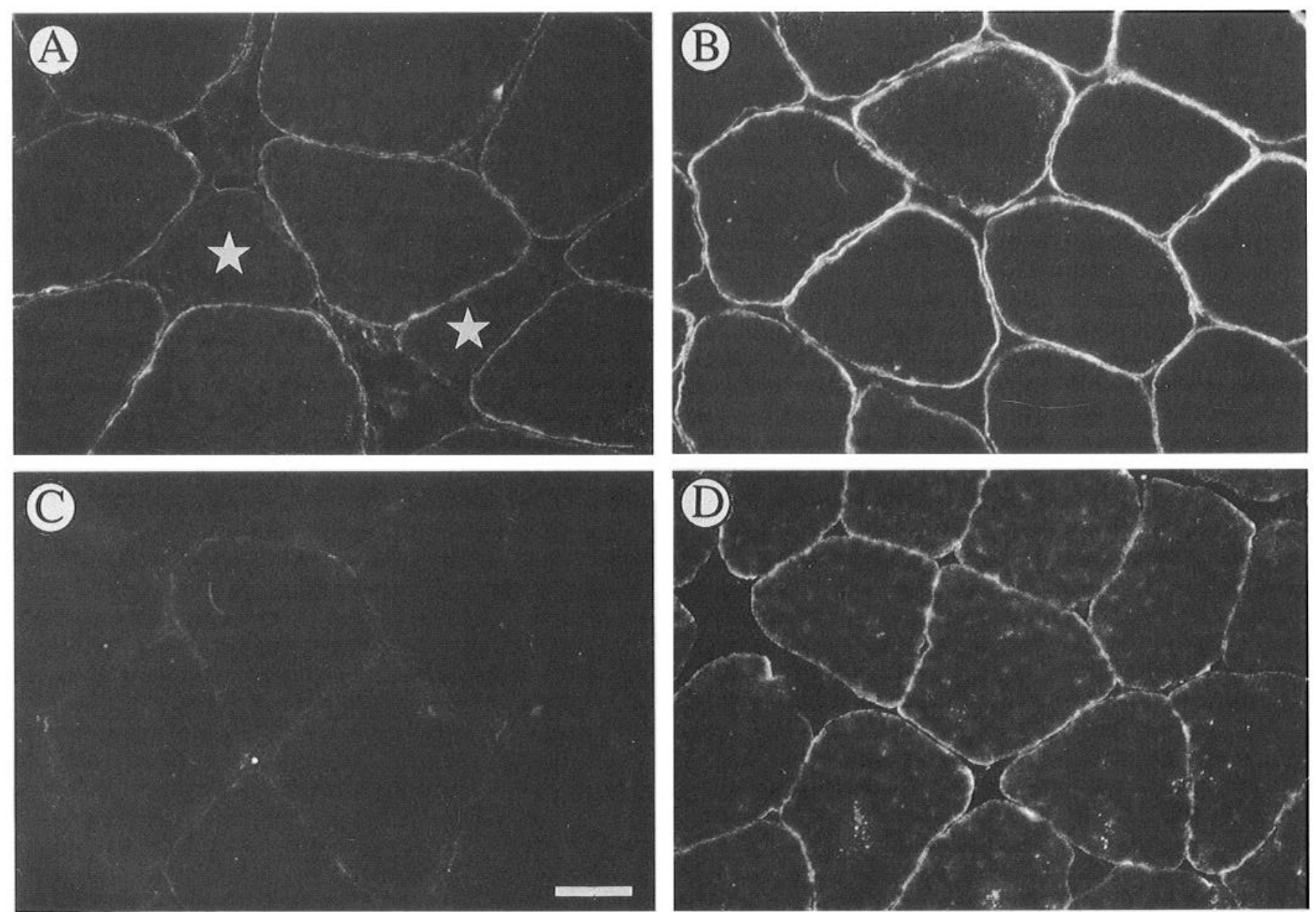

Figure 6. Modulation of muscle fiber N-cadherin expression by behavioral activity: cryostat sections from the medial gastrocnemius doubly stained with NCD-2 and CaS/Cl mAbs; only the NCD-2 image is shown. Regions of the section were chosen that contained almost exclusively tonic fibers; all fibers except those indicated by stars in $A$ were $\mathrm{mAb} \mathrm{CaS} / \mathrm{Cl}$ positive. $A$, Innervated muscle from a normally caged animal. $B$, Muscle denervated $6 \mathrm{~d}$ from a normally caged animal. $C$, Innervated muscle from a chicken housed for 3 weeks in a "free-range" enclosure. $D$, Innervated muscle from a chicken housed for 3 weeks in the "free-range" enclosure and then returned to the normal cage for 3 weeks. The lowlevel expression of $\mathrm{N}$-cadherin by innervated tonic fibers can be reversibly regulated by changes in housing-induced limits to normal motor activity. Scale bar, $30 \mu \mathrm{m}$.

\section{Discussion}

Our results show that the pattern of expression of $\mathrm{N}$-cadherin by skeletal muscle fibers is inversely correlated with their functional innervation. During chick limb development, $\mathrm{N}$-cadherin mRNA levels decreased 15-fold during a 6 d period (St. 3340). This decrease is temporally coincident with the development of robust spinal cord electrical and hindlimb locomotor activity (Hamburger et al., 1965; Provine, 1972; Oppenheim, 1975), both of which increase fourfold during this period to reach a peak at embryonic day $13(\approx$ St. 39$)$. We found that blockade of neuromuscular transmission for $48 \mathrm{hr}$ using $d$-tubocurare partially reversed this developmental decline in $\mathrm{N}$-cadherin mRNA levels, suggesting a causal link between increased neuromuscular activity and decreased levels of $\mathrm{N}$-cadherin mRNA during development. In the adult, $\mathrm{N}$-cadherin expression was undetectable by immunofluorescence and immunoblotting on twitch fibers but was reexpressed within days of denervation, providing a clear demonstration of the role of muscle fiber innervation in downregulating $\mathrm{N}$-cadherin gene expression. In contrast to adult twitch fibers, multiply innervated tonic fibers continued to express low levels of $\mathrm{N}$-cadherin in control adult chickens. This continued expression of detectable $\mathrm{N}$-cadherin in normally innervated tonic muscle fibers provided an interesting opportunity to modulate $\mathrm{N}$-cadherin expression without surgical intervention. By housing chickens as a group in a large enclosure to stimulate increased behavioral motor activity, we were able to decrease levels of tonic fiber $\mathrm{N}$-cadherin expression reversibly. These results suggest that the neural regulation of muscle $\mathrm{N}$-cadherin expression may occur as a continuum rather than as either only high or low levels of expression. In their elegant studies of ACh receptor expression, Lomo and Westgaard (1975) have shown that bursts of high-frequency stimulation are more important in downregulating muscle fiber ACh sensitivity than are the total number of stimuli given over a several day period. Thus, although we did not quantitate the increased motor activity for our group-housed free-ranging chickens, periods of intense motor activity during running and jumping, which were frequent in this setting but which never occurred in the standard cage housing, may be of particular importance in downregulating $\mathrm{N}$-cadherin levels in slow-tonic fibers.

One functional consequence of the activity-dependent regulation of $\mathrm{N}$-cadherin expression in muscle fibers may be to mod- 
ulate the attractiveness of muscle fibers to growing axons. Bixby et al. (1987) have shown that anti-N-cadherin antibodies reduce neurite outgrowth from cultured ciliary ganglion neurons plated on primary chick myotubes. The downregulation of muscle Ncadherin on twitch fibers during development may thus participate in limiting the growth of axons beyond the initial site of synapse formation. In contrast, the prolonged expression of $\mathrm{N}$ cadherin by developing multiply innervated tonic as compared with focally innervated twitch fibers may be important for the development of additional synapses in growing tonic fibers. Although fundamental differences in the pattern of intramuscular nerve branching in tonic versus twitch muscles are well established by St. 32-34 (Dahm and Landmesser, 1988), before the time when we began to observe differences in tonic versus twitch fiber expression of N-cadherin (St. 36-37), at later stages of development nerve side branches and synapses continue to be added along the length of elongating tonic but not twitch muscles. Thus, the continued expression of $\mathrm{N}$-cadherin on tonic fibers could play a permissive role in maintaining the attractiveness of tonic muscle fiber surfaces for the establishment of new synapses during later stages of development.

In the adult animal, muscle fiber $\mathrm{N}$-cadherin may enhance the attractiveness of denervated fibers to regenerating axons. Cell surface-associated factors present on denervated muscle fibers stimulate longer and more highly branched neurite outgrowth in vitro as compared to innervated fibers (Covault et al., 1987). NCAM is thought to be one factor that contributes to this increased neural attractiveness of denervated fibers (Booth et al., 1990). Our results suggest that $\mathrm{N}$-cadherin may be a second such neurally active cell surface component enriched on denervated muscle fibers. Studies examining the effects of anti$\mathrm{N}$-cadherin blocking antibody injection into partially denervated adult muscle, similar to those carried out by Booth et al. (1990) with anti-NCAM, would be important in further testing this idea. In view of the comparatively low levels of $\mathrm{N}$-cadherin cxpressed by spinal motor neurons (Hatta et al., 1987; Covault, unpublished observations) together with the recent identification of several additional neural cadherins (Inuzuka et al., 1991; Napolitano et al., 1991; Ranscht and Dours, 1991; Suzuki et al., 1991), it will be important to consider the involvement of muscle $\mathrm{N}$-cadherin in both homophilic and heterophilic cadherin-mediated interactions with spinal motor neurons. Both types of adhesion have been demonstrated among members of the cadherin family of adhesion molecules (Hirano et al., 1987; Volk et al., 1987; Inuzuka et al., 1991).

In addition to nerve-muscle interactions, two other roles for $\mathrm{N}$-cadherin-mediated adhesion have been suggested in the neuromuscular system. Knudsen et al. (1990) have shown that anti$\mathrm{N}$-cadherin antibodies can reduce myoblast-myoblast adhesion and myotube formation in vitro and have proposed that $\mathrm{N}$ cadherin together with NCAM may play an important role in promoting myotube formation. The downregulation of muscle fiber $\mathrm{N}$-cadherin during development thus might limit the number of myoblasts fusing with individual myotubes. In contrast, increases in $\mathrm{N}$-cadherin expression induced by curare treatment may contribute to the development of excessively large myotube clusters in curare-treated embryos (B. J. Fredette and L. T. Landmesser, unpublished observations). Finally, N-cadherin has been shown to be an important component of the Schwann cell membrane involved in the stimulation of neurite growth in vitro (Bixby et al., 1988; Letourneau et al., 1990). In this study, we noted that denervation induces the accumulation of high levels

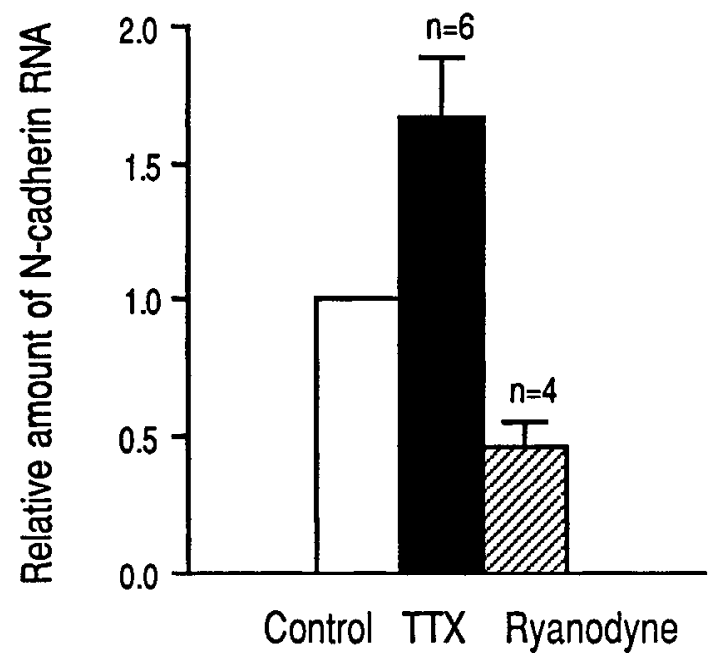

Figure 7. Regulation of $\mathrm{N}$-cadherin mRNA levels in primary muscle cultures: relative amounts of N-cadherin mRNA in control and TTXand ryanodine-treated primary chick myotube cultures as determined using the RNase protection assay. The amount of $\mathrm{N}$-cadherin mRNA in drug-treated cultures is expressed relative to that in untreated sister cultures from the same experiment. The results shown are the average ratio from several experiments. Blockade of spontaneous activity by TTX for $48 \mathrm{hr}$ produced a $65 \%$ increase in N-cadherin mRNA levels, while $48 \mathrm{hr}$ exposure to the calcium channel agonist ryanodine reduced $\mathrm{N}$-cadherin mRNA levels by $50 \%$ as compared to control cultures.

of $\mathrm{N}$-cadherin in association with Schwann cells and their associated basal lamina tubes in lesioned peripheral nerve. In light of the important role that these components provide during the regeneration of motor and sensory axons, our results suggest that $\mathrm{N}$-cadherin may play an important functional role during the process of nerve regeneration.

Results of our studies of $\mathrm{N}$-cadherin gene expression in primary myotube cultures suggest that increases in myoplasmic free calcium triggered by membrane depolarization may provide the initial second messenger linking nerve activation and muscle $\mathrm{N}$-cadherin downregulation. Similar studies of ACh receptor gene expression have led previous authors to propose a central involvement of calcium in the neural regulation of those genes (Pezzementi and Schmidt, 1981; Rubin, 1985; Klarsfeld et al., 1989). It is interesting to note in this respect that a key distinction between tonic and twitch fibers involves differences in the time course and maximal peak of intracellular calcium transients elicited by muscle fiber depolarization (Miledi et al., $1977 \mathrm{a}, \mathrm{b})$. Tonic fibers are characterized by lower peak and much slower calcium transients as compared with twitch fibers. Distinctions in these fiber type-specific calcium transients reflect differences in the degree of organization of their respective $T$ tubular-sarcoplasmic reticulum systems (Page and Slater, 1965; Hess, 1967) as well as their expression of different isoforms of $\mathrm{Ca}^{2+}$ ATPase (Fig. 4; Kaprielian and Fambrough, 1987). These differences in muscle fiber calcium metabolism between twitch and slow-tonic fibers are clearly important in producing their respective contractile properties and may also produce differences in the level of $\mathrm{N}$-cadherin expression in slow-tonic as compared with fast- or slow-twitch fibers.

Our results show that the pattern of $\mathrm{N}$-cadherin expression in chicken skeletal muscle fibers roughly parallels that previously described for NCAM (Covault and Sanes, 1985, 1986; Tosney et al., 1986). Both are expressed during development 
on myoblast and myotubes, are downregulated to very low levels on twitch fibers, and are reexpressed following denervation of adult muscle. In spite of these overall similarities in the regulation of N-cadherin and NCAM gene expression in chick muscle, there are several important distinctions. First, although both are upregulated within days of denervation in adult twitch fibers, the decline in NCAM mRNA and protein during development lag behind that of $\mathrm{N}$-cadherin by approximately $3 \mathrm{~d}$. Second, although adult slow-tonic fibers express both $\mathrm{N}$-cadherin (present results) and NCAM (Bleisch et al., 1989; Covault, unpublished observations), levels of NCAM on innervated slow-tonic fibers are quite high and are little changed either by denervation or by increased motor activity associated with our "free-range group housing" (Covault, unpublished observations). Finally, NCAM mRNA levels are not increased in TTX paralyzed primary myotube cultures, but like $\mathrm{N}$-cadherin, NCAM mRNA levels are decreased $\approx 50 \%$ following a $48 \mathrm{hr}$ exposure to ryanodine (C.-g. Hahn, unpublished observations). Thus, muscle fiber $\mathrm{N}$-cadherin gene expression is more closely coupled to neural activation than is NCAM gene expression. The downregulation of NCAM expression may require a higher intensity of neural stimulation or a more highly developed ionic response than required for the downregulation of $\mathrm{N}$-cadherin expression. For example, during development, while nerve-induced muscle contractions can be detected as early as St. 28 (Landmesser and Morris, 1975), the myotube membrane's electrical response to nerve stimulation is predominately passive (e.g., receptor potential only) until after embryonic day 15 (St. 40-41; Kano, 1975). Additionally, the T-tubular system, which is essential for the tight coupling of depolarization and the release of sarcoplasmic reticulum calcium stores, also develops around St. 40. Thus, the intracellular second messenger response to neural stimulation is most likely comparatively low early in muscle development and could reach a threshold sufficient for the downregulation of $\mathrm{N}$-cadherin significantly earlier than that for NCAM. Similarly, the absence of both spiking action potentials (Korenaga, 1980) and a highly developed T-tubular system (Page and Slater, 1965; Hess, 1967) in adult slow-tonic fibers may preclude a significant neural downregulation of NCAM as compared with $\mathrm{N}$-cadherin gene expression in slow-tonic fibers. Quantitative studies comparing changes in levels of myoplasmic free calcium with changes in the expression of and $\mathrm{N}$-cadherin and NCAM will be important to test our hypothesis that calcium plays a central role linking muscle fiber stimulation and the downregulation of these genes.

\section{References}

Bixby JL, Zhang R (1990) Purified N-cadherin is a potent substrate for the rapid induction of neurite outgrowth. J Cell Biol 110:12531260.

Bixby JL, Pratt RS, Lilien J, Reichardt LF (1987) Neurite outgrowth on muscle cell surfaces involves extracellular matrix receptors as well as $\mathrm{Ca}^{2+-d e p e n d e n t ~ a n d ~-i n d e p e n d e n t ~ c e l l ~ a d h e s i o n ~ m o l e c u l e s . ~ P r o c ~}$ Natl Acad Sci USA 84:2555-2559.

Bixby JL, Lilien J, Reichardt LF (1988) Identification of the major proteins that promote neuronal process outgrowth on Schwann cells in vitro. J Cell Biol 107:353-361.

Bleisch W, Scharff C, Nottcbohm F (1989) Neural cell adhesion molecule (N-CAM) is elevated in adult avian slow muscle fibers with multiple terminals. Proc Natl Acad Sci USA 86:6403-6407.

Booth CM, Kemplay SK, Brown MC (1990) An antibody to neural cell adhesion molecule impairs motor nerve terminal sprouting in a mouse muscle locally paralyzed with botulinum toxin. Neuroscience 35:85-91.
Cashman NR, Covault J, Wollman RL, Sanes JR (1987) Neural cell adhesion molecule in normal, dencrvated, and myopathic human muscle. Ann Neurol 21:481-489.

Chirgwin JM, Przybyla AE, MacDonald RJ, Rutter WJ (1979) Isolation of biologically active ribonucleic acid from sources enriched in ribonuclease. Biochemistry 18:5294-5299.

Chiu AY, Matthew WD, Patterson PH (1986) A monoclonal antibody that blocks the activity of a neurite regeneration-promoting factor: studies on the binding site and its localization in vivo. J Cell Biol 102 1383-1398.

Chomczynski P, Sacchi N (1987) Single-step method of RNA isolation by acid guanidinium thiocyanate-phenol-chloroform extraction. Anal Biochem 162:156-159.

Covault J (1989) Molecular biology of cell adhesion in neural development. In: Molecular neurobiology (Glover DM, Hames BD, eds), pp 143-200. Washington, DC: IRL.

Covault J, Sanes JR (1985) Neural cell adhesion molecule (N-CAM) accumulates in denervated and paralyzed skeletal muscles. Proc Natl Acad Sci USA 82:4544-4548.

Covault J, Sanes JR (1986) Distribution of N-CAM is synaptic and extrasynaptic portions of developing and adult skeletal muscle. J Cell Biol 102:716-730.

Covault J, Cunningham JM, Sanes JR (1987) Neurite outgrowth on cryostat sections of innervated and denervated skeletal muscle. J Cell Biol 105:2479-2488.

Dahm LM, Landmesser LT (1988) The regulation of intramuscular nerve branching during normal development and following activity blockade. Dev Biol 130:621-644.

Dahm LM, Landmesser LT (1991) The regulation of synaptogenesis during normal development and following activity blockade. J Neurosci 11:238-255.

Detrick RJ, Dickey D, Kintner CR (1990) The effects of N-cadherin misexpression on morphogenesis in Xenopus embryos. Neuron 4: 493-506.

Drazba J, Lemmon V (1990) The role of cell adhesion molecules in neurite outgrowth on Mueller cells. Dev Biol 138:82-93.

Dugaiczyk A, Haron JA, Stone EM, Dennison OE, Rothblum KN, Schwartz RJ (1983) Cloning and sequencing of a deoxyribonucleic acid copy of glyceraldehyde-3-phosphate dehydrogenase messenger ribonucleic acid isolated from chicken muscle. Biochemistry 22:16051613.

Fredette BJ, Landmesser LT (1991) A reevaluation of the role of innervation in primary and secondary myogenesis in developing chick muscle. Dev Biol 143:19-35.

Fujimori T, Miyatani S, Takeichi M (1990) Ectopic expression of Ncadherin perturbs histogenesis in Xenopus embryos. Development 110:97-104.

Hamburger V, Hamilton HL (1951) A series of normal stages in the development of the chick embryo. J Morphol 88:49-82.

Hamburger V, Balaban M, Oppenheim R, Wenger E (1965) Periodic motility of normal and spinal chick embryos between 8 and 17 days of incubation. J Exp Zool 159:1-14.

Hatta K, Takeichi M (1986) Expression of N-cadherin adhesion molecules associated with early morphogenetic events in chick development. Nature 320:447-449.

Hatta K, Takagi S, Fujisawa H, Takeichi M (1987) Spatial and temporal expression pattern of $\mathrm{N}$-cadherin cell adhesion molecules correlated with morphogenetic processes of chicken embryos. Dev Biol 120:215-227.

Hatta K, Nose A, Nagafuchi A, Takeichi M (1988) Cloning and expression of cDNA encoding a neural calcium-dependent cell adhesion molecule: its identity in the cadherin gene family. J Cell Biol 106: 873-881.

Hemperly JJ, Murray BA, Edelman GM, Cunningham BA (1986) Sequence of a cDNA clone encoding the polysialic acid-rich and cytoplasmic domains of the neural cell adhesion molecule N-CAM. Proc Natl Acad Sci USA 83:3037-3041.

Hess A (1967) The structure of vertebrate slow and twitch muscle fibers. Invest Ophthalmol 6:217-228.

Hirano S, Nose A, Hatta K, Kawakami A, Takeichi M (1987) Calciumdependent cell-cell adhesion molecules (cadherins): subclass specificities and possible involvement of actin bundles. J Cell Biol 105:25012510.

Hunter DD, Shah V, Merlie JP, Sanes JR (1989) A laminin-like ad- 
hesive protein concentrated in the synaptic cleft of the neuromuscular junction. Nature 338:229-234.

Inuzuka H, Miyatani S, Takeichi M (1991) R-cadherin: a novel calcium-dependent cell-cell adhesion molecule expressed in the retina. Neuron 7:69-79.

Johnson GD, De C Nogueira Araujo GM (1981) A simple method of reducing the fading immunofluorescence during microscopy. $J$ Immunol Methods 43:349-350.

Kano M (1975) Development of excitability in embryonic chick skeletal muscle cells. J Cell Physiol 86:503-510.

Kaprielian Z, Fambrough DM (1987) Expression of fast and slow isoforms of the calcium ATPase in developing chick skeletal muscle. Dev Biol 124:490-503.

Klarsfeld A, Laufer R, Fontaine B, Devillers-Thiery A, Dubreuil C, Changeux JP (1989) Regulation of muscle AChR a-subunit gene expression by electrical activity: involvement of protein kinase $\mathrm{C}$ and Ca. Neuron 2:1229-1236.

Knudsen KA, Myers L, McElwee SA (1990) A role for the $\mathrm{Ca}^{2}$. dependent adhesion molecule, $\mathrm{N}$-cadherin in myoblast interactions during myogenesis. Exp Cell Res 188:175-184.

Korenaga S (1980) Electrical properties of muscle membrane and of neuromuscular junctions in normal and dystrophic chickens. Jpn J Physiol 30:313-331.

Landmesser L, Morris D (1975) The development of functional innervation in the hindlimb. J Physiol (Lond) 249:301-326.

Landmesser L, Dahm L, Schultz K, Rutishauser U (1988) Distinct roles for adhesion molecules during innervation of embryonic chick muscle. Dev Biol 130:645-670.

Letourneau PC, Shattuck TA, Roche FK, Takcichi M, Lemmon V (1990) Nerve growth cone migration onto Schwann cells involves the calcium-dependent adhesion molecule, N-cadherin. Dev Biol 138:430442.

Little PFR, Jackson IJ (1987) Application of plasmids containing promoters specific for phage-encoded RNA polymerases. In: DNA cloning, Vol III (Glover DM, ed), pp 1-18. Washington, DC: IRL.

Lomo T, Westgaard RH (1975) Further studies on the control of ACh sensitivity by muscle activity in the rat. J Physiol (Lond) 252:603626.

Matsunaga M, Hatta K, Nagafuchi A, Takeichi M (1988) Guidance of optic nerve fibres by $\mathrm{N}$-cadherin adhesion molecules. Nature 334: 62-64.

Miledi R, Parker I, Schalow G (1977a) Calcium transients in frog slow muscle fibres. Nature 268:750-752.

Miledi R, Parker I, Schalow G (1977b) Measurement of calcium transients in frog muscle by the use of arsenazo III. Proc R Soc Lond [Biol] 198:201-210.

Miller JB, Crow MT, Stockdale FE (1985) Slow and fast myosin heavy chain content defines three types of myotubes in early muscle cell cultures. J Cell Biol 101:1643-1650.

Moore SE, Walsh FS (1985) Specific regulation of N-CAM/D2-CAM cell adhesion molecule during skeletal muscle development. EMBO J 4:623-630.

Moore SE, Walsh FS (1986) Nerve dependent regulation of neural cell adhesion molecule expression in skeletal muscle. Ncuroscience 18: 499-505
Napolitano EW, Venstrom K, Wheeler EF, Reichardt LF (1991) Molecular cloning and characterization of B-cadherin, a novel chick cadherin. J Cell Biol 113:893-905.

Oppenheim RW (1975) The role of supraspinal input in embryonic motility: a re-examination in the chick. J Comp Neurol 160:37-50.

Owens GC, Edelman GM, Cunningham BA (1987) Organization of the neural cell adhesion molecule (N-CAM) gene: alternative exon usage as the basis for different membrane-associated domains. Proc Natl Acad Sci USA 84:294-298.

Page S, Slater CR (1965) Observations on the fine structure and rate of contraction of some muscles from the chicken. J Physiol (Lond) 179:58-59.

Pezzementi L, Schmidt J (1981) Ryanodine alters the rate of acetylcholine receptor synthesis in chick skeletal muscle cell cultures. J Biol Chem 256:12651-12654.

Provine RR (1972) Ontogeny of bioelectric activity in the spinal cord of the chick embryo and its behavioral implications. Brain Res 41: 365-378.

Ranscht B, Dours-Zimmermann MT (1991) T-cadherin, a novel cadherin cell adhesion molecule in the nervous system lacks the conserved cytoplasmic region. Neuron 7:391-402.

Rieger F, Grumet M, Edelman GM (1985) N-CAM at the vertebrate neuromuscular junction. J Cell Biol 101:285-293.

Rubin LL (1985) Increases in muscle $\mathrm{Ca}^{2+}$ mediate changes in acetylcholinesterase and acetylcholine receptors caused by muscle contraction. Proc Natl Acad Sci USA 82:7121-7125.

Rutishauser U. Jessel TM (1988) Cell adhesion molecules in vertebrate development. Physiol Rev 68:819-857.

Rutishauser U, Grumet M, Edelman GM (1983) Neural cell adhesion molecule mediates initial interactions between spinal cord neurons and muscle cells in culture. J Cell Biol 97:145-152.

Rutishauser U, Acheson A, Hall AK, Mann DM, Sunshine J (1988) The neural cell adhesion molecule (NCAM) as a regulator of cell-cell interactions. Science 240:53-57.

Sanes JR, Schachner M, Covault J (1986) Expression of several adhesive macromolecules (N-CAM, Ll, J1, NILE, uvomorulin, laminin, fibronectin and a heparan sulfate proteoglycan) in embryonic, adult and denervated adult skeletal muscles. J Cell Biol 102:420-431.

Suzuki S, Sano K, Tanihara H (1991) Diversity of the cadherin family: evidence for eight new cadherins in nervous tissue. Cell Regul 2:261270.

Takeichi M (1990) Cadherins: a molecular family important in selective cell-cell adhesion. Annu Rev Biochem 59:237-252.

Tomaselli KJ, Neugebauer KM, Bixby JL, Lilien J, Reichardt LF (1988) $\mathrm{N}$-cadherin and integrins: two receptor systems that mediate neuronal process outgrowth on astrocyte surfaces. Neuron 1:33-43.

Tosncy KW, Watanabe M, Landmesser L, Rutishauser U (1986) The distribution of NCAM in the chick hindlimb during axon outgrowth and synaptogenesis. Dev Biol 114:437-452.

Towbin H, Staehelin T, Gordon J (1979) Electrophoretic transfer of proteins from polyacrylamide gels to nitrocellulose sheets. Procedure and some applications. Proc Natl Acad Sci USA 76:4350-4354.

Volk T, Cohen O, Geiger B (1987) Formation of heterotypic adherenstype junctions between L-CAM-containing liver cells and A-CAMcontaining lens cells. Cell 50:987-994. 